\title{
Medical Device-Related Pressure Injuries: an integrative literature review
}

\author{
Lesões por Pressão Relacionadas a Dispositivos Médicos: revisão integrativa da literatura \\ Lesiones por Presión Relacionadas a Dispositivos Médicos: revisión integrativa de la literatura
}

Sabrina Guterres da Silva Galetto'
ORCID: 0000-0003-4137-1687

Eliane Regina Pereira do Nascimento' ORCID: 0000-0003-2215-4222

Patrícia Madalena Vieira Hermida' ORCID: 0000-0002-7969-357X

Luciana Bihain Hagemann de Malfussi' ORCID: 0000-0002-3199-9529

' Universidade Federal de Santa Catarina. Programa de PósGraduação em Enfermagem. Florianópolis-SC, Brasil.

How to cite this article:

Galetto SGS, Nascimento ERP, Hermida PMV, Malfussi LBH.

Medical Device-Related Pressure Injuries: an integrative literature review. Rev Bras Enferm. 2019;72(2):505-12. doi: http://dx.doi.org/10.1590/0034-7167-2018-0530

Corresponding Author:

Sabrina Guterres da Silva Galetto E-mail: sabrinaguterres@gmail.com

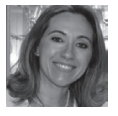

Submission: 05-05-2018 Approval: 08-06-2018

\section{ABSTRACT}

Objetives: To identify and analyze the scientific evidence regarding the occurrence of Medical Device-Related Pressure Injuries, considering the development sites; and to describe the devices of risk and the measures of prevention and treatment. Method: Integrative, search-based review: CINAHL, PubMed, Wiley InterScience, Scopus, and Web Of Science. The terms "pressure ulcer" and "medical devices" were used, including original articles and case studies published between 2010 and 2015. Nine studies were selected. Results: Posterior cervical region and nose had the highest injury frequencies, respectively, $66.0 \%$ and $40.0 \%$. Eleven risk devices were identified, with emphasis on Non-Invasive Ventilation masks and orotracheal tube. For prevention and treatment emerged recommendations specific to the device employed and general measures. Conclusion: Medical Device-Related Pressure Injuries are frequent problems, however, they can be prevented and treated based on the recommendations of the articles raised in this review.

Descriptors: Nursing; Nursing Care; Pressure Ulcer; Equipment and Supplies; Patient Safety.

\section{RESUMO}

Objetivo: Identificar e analisar as evidências científicas quanto à ocorrência de Lesões por Pressão Relacionadas a Dispositivos Médicos, considerando os locais de desenvolvimento; e descrever os dispositivos de risco e as medidas de prevenção e tratamento. Método: Revisão integrativa, com busca nas bases: CINAHL, PubMed, Wiley InterScience, Scopus e Web Of Science. Utilizou-se os termos "pressure ulcer" e "medical devices", sendo incluídos artigos originais e estudos de caso, publicados entre 2010 e 2015 . Foram selecionados nove estudos. Resultados: Região cervical posterior e o nariz obtiveram as frequências mais elevadas de lesões, respectivamente, $66,0 \%$ e $40,0 \%$. Identificaram-se onze dispositivos de risco, destacando-se as máscaras de Ventilação Não Invasiva e o tubo orotraqueal. Para prevenção e tratamento emergiram recomendações específicas ao dispositivo empregado e medidas gerais. Conclusão: As Lesões por Pressão Relacionadas a Dispositivos Médicos são problemas frequentes, todavia, podem ser prevenidas e tratadas com base nas recomendações dos artigos levantados nesta revisão.

Descritores: Enfermagem; Cuidados de Enfermagem; Lesão por Pressão; Equipamentos e Provisões; Segurança do Paciente.

\section{RESUMEN}

Objetivo: Identificar y analizar las pruebas científicas sobre la ocurrencia de lesiones por presión relacionadas con dispositivos médicos, considerando los sitios de desarrollo; y describir los dispositivos de riesgo y las medidas de prevención y tratamiento. Método: Revisión Integrativa, con búsqueda en las bases: CINAHL, PubMed, Wiley Interscience, Scopus y Web of Science. Se utilizaron los términos "pressure ulcer" y "medical devices", incluidos los artículos originales y los estudios de caso, publicados entre 2010 y 2015. Se seleccionaron nueve estudios. Resultados: La región y la nariz cervicales posteriores obtuvieron las frecuencias más altas de lesiones, respectivamente, $66,0 \%$ y $40,0 \%$. Se identificaron once dispositivos de riesgo, destacando las máscaras de ventilación no invasiva y el tubo orotraqueal. Para la prevención y el tratamiento surgieron recomendaciones específicas para el dispositivo empleado y las medidas generales. Conclusión: Las Lesiones por Presión Relacionadas a Dispositivos Médicos son problemas frecuentes, sin embargo, pueden ser prevenidas y tratadas con base en las recomendaciones de los artículos levantados en esta revisión.

Descriptores: Enfermería; Cuidados de Enfermería; Úlcera por Presión; Equipos y Provisiones; Seguridad del Paciente. 


\section{INTRODUCTION}

Patient safety and quality of health care are themes that are gaining prominence on the world stage. Campaigns and studies are carried out in several areas of knowledge with the main objective of promoting a damage-free care.

An international initiative worthy of mention is the global alliance for patient safety, established in 2004 by the World Health Organization, whose mission is to coordinate, disseminate and accelerate improvements related to the theme ${ }^{(1)}$. Politically committed to this mission, the Brazilian Ministry of Health launched in 2013 the Brazilian National Patient Safety Program (PNSP - Programa Nacional de Segurança do Paciente), which provides, among other strategies, the elaboration and implementation of protocols, guides and manuals for the prevention of Pressure injury $(\mathrm{PI})^{(2)}$. Regarding this type of injury, it is essential to mention that in 2016, the National Pressure Ulcer Advisory Panel (NPUAP) announced a change in the terminology "Pressure ulcer"for PI, considering that the term describes it more precisely, both intact and injuried skin ${ }^{(3)}$.

Pls are a reason for concern in health institutions, because in addition to generating negative impact on patients and their families due to pain, delayed functional recovery and infections, they have repercussions on prolonged hospitalizations, higher costs to institutions and increased morbidity and mortality ${ }^{(2)}$. NPUAP defines PI as a damage in the underlying skin and/or soft tissues, usually over a prominent bone or related to the use of a medical device or other artifact. The injury, which appears in full skin or as an open injury, can be painful and occurs as a result of intense and/or prolonged pressure in combination with shear. Tolerance of soft tissue under pressure and shear can also be affected by microclimate, nutrition, perfusion, comorbidities and condition of the tissue itself ${ }^{(3)}$.

PIs can occur in various body locations and come in various sizes. Its severity is related to the layer of affected tissue, which may involve from the epidermis to the underlying muscle and bone $^{(3-4)}$. In order to classify PI's severity, NPUAP proposed a system that considers how stages/degrees of development of the same: Stage 1 - whole skin with erythema that does not whiten; Stage 2 - loss of skin in its partial thickness with dermis exposure; Stage 3 - loss of skin in its overall thickness; Stage 4 - loss of skin in its total thickness and tissue loss. Pls can still be classified into Unclassified Pressure Injury and Deep Tissue Pressure Injury ${ }^{(3)}$.

There is a large scientific production of $\mathrm{P}^{(4)}$, which usually focuses on decubitus injuries located in regions of bony prominences such as sacrum and calcaneum. It is known that the occurrence of PI in these locations is quite frequent, however, these can occur in any tissue under pressure, therefore also develop in atypical sites, such as the urethra, mouth, ear, among others ${ }^{(5-6)}$.

$\mathrm{PI}$ formation in unusual regions is usually caused by the use of medical devices, such as probes and catheters ${ }^{(5)}$, which are then called Medical Device-Related Injuries (MDRI), which are created and applied for diagnostic purposes and therapies. The definition of MDRI was included in the NPUAP update, as well as the Pressure Injury in Mucous Membrane ${ }^{(3)}$.

MDRIs usually display the device pattern or shape and should be categorized according to the PU classification system. NPUAP recognizes that MDRIs are increasingly recurrent in care settings, and although they are not a new phenomenon, they have only received ${ }^{(3)}$.
The relevance of the review of studies focused on the MDRI is related to the possibility of knowing the knowledge gaps on the subject, but, above all, to the development of new research aimed at the prevention of these injuries, thus contributing to patient safety

\section{OBJETIVE}

This study aims to identify and analyze the scientific evidence regarding the occurrence of Medical Device-Related Pressure Injuries, considering the development sites; and describe the devices of risk and the measures of prevention and treatment.

\section{METHOD}

This is an integrative review of the literature, which allows us to perform analyzes that extrapolate the synthesis of the results of primary studies, with the potential to develop new theories and research problems ${ }^{(7)}$.

The study comprised the steps proposed by Ganong ${ }^{(8)}$ : Selection of the research question; definition of the inclusion and exclusion criteria of the studies and selection of the sample; representation of the selected studies in table format, considering the characteristics in common; critical analysis of findings; interpretation of results; and to report clearly the evidence found.

Thus, the guiding questions of this study were: What is the occurrence of MDRI in hospitalized patients according to their developmental sites? What are the risk devices for this type of injury? What measures are used for the prevention and treatment of these injuries?

The literature search occurred in December 2015 in the journal Portal of the Coordination of Improvement of Higher Education Personnel (CAPES - Coordenação de Aperfeiçoamento de Pessoal de Nível Superior) of the Brazilian Ministry of Education (MEC Ministério da Educação), via the Virtual Private Network (VPN) of the Universidade Federal de Santa Catarina, and included the databases: Cumulative Index to Nursing and Allied Health Literature (CINAHL); U.S. National Library of Medicine (PubMed); Wiley InterScience; Scopus; and, Web of Science (WOS).

The search strategies used to locate the studies were adapted to each database, based on the research question and the inclusion and exclusion criteria established. The terms used in the search were: "pressure ulcer" AND "medical devices".

For the selection of the sample, carried out by one of the researchers, the inclusion criteria were: Original study (research) or case study, quantitative or qualitative approach, published electronically in full, in an indexed journal, in the form of an article, in Portuguese, English or Spanish, in the time cut from 2010 to 2015. The study should also address, in the title or abstract, injury/ Pressure Injury arising from medical device. Review articles, experience reports, letters, editorials, theses, dissertations, monographs, books, works not related to the scope of the study or that did not answer the guiding questions of this review and the duplicate production in the researched databases were excluded. The selection of the studies followed the recommendations of the Statement for Reporting Systematic Reviews and Meta-Analyses of Studies - PRISMA ${ }^{(9)}$, as shown in Figure 1. 


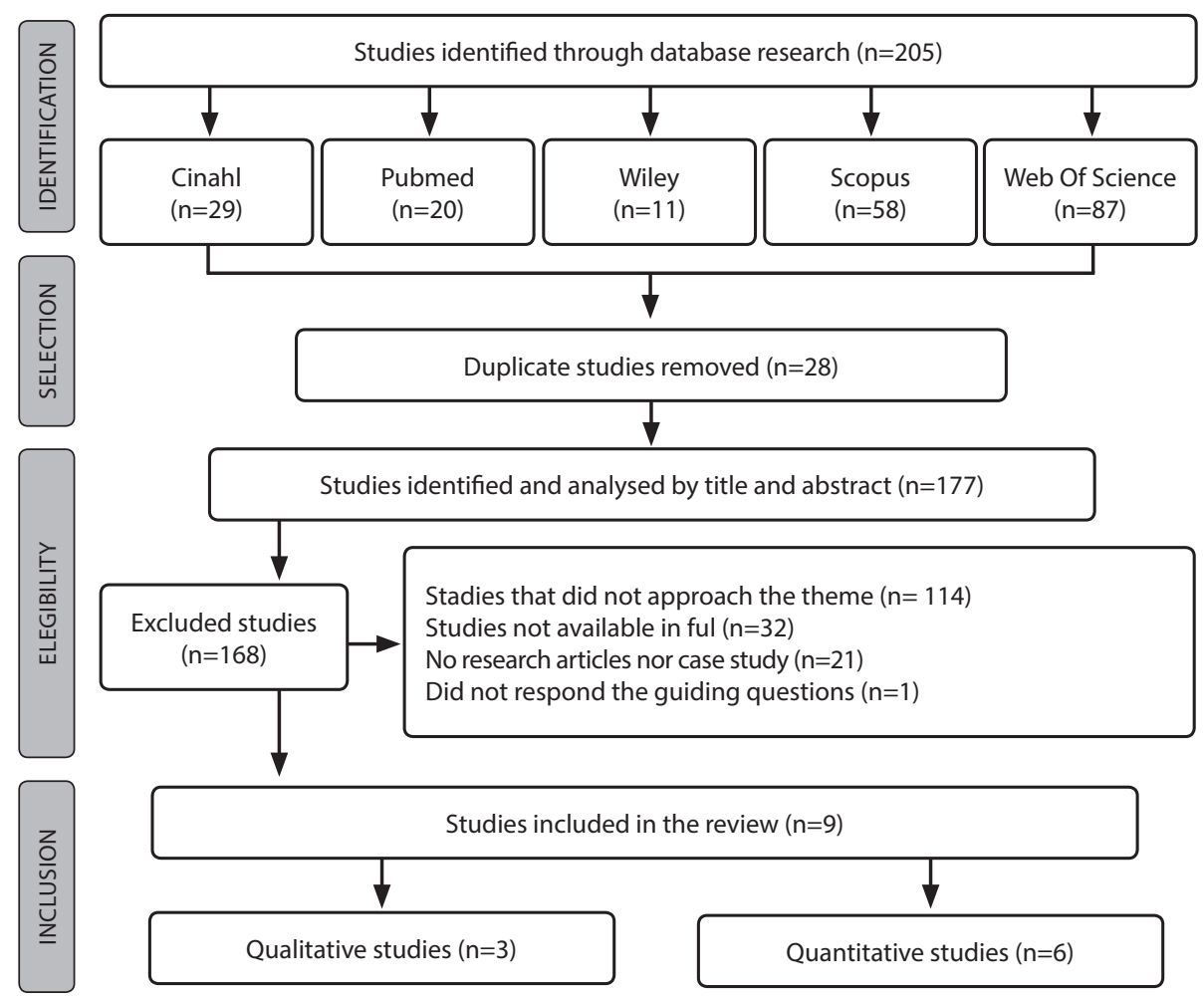

Figure 1 - Flowchart for identification and selection of studies, based on the PRISMA recommendation of all relevant Randomized Clinical Trials (RCTs); Level II: Evidence obtained from well-planned RCTs; Level III: Evidence from well-outlined controlled trials without randomization; Level IV: Evidence from well-outlined cases and cohort studies; Level V: Evidence of systematic reviews of descriptive and qualitative studies; Level VI: Evidence from unique descriptive or qualitative studies; Level VII: Evidence from the opinion of authorities and/or reports from expert committees ${ }^{(10)}$.

Because this is an integrative review of the literature, this study did not require the approval of the Research Ethics Committee, however, ethical aspects such as the citation of the authors of the selected articles were considered.

\section{RESULTS}

The database search, considering the inclusion and exclusion criteria, resulted in the initial selection of 205
For the organization and analysis of the selected studies, a tool was used, elaborated by one of the researchers, constituted by the data:Title; year of publication; country of research; study outlining; number of patients participating; objective of the research and main results; level of evidence; frequency of occurrence and location of $\mathrm{Pl}$; type of medical device that caused the injury; methods of prevention and treatment of PI. Each study was identified by a code consisting of the letter (study) followed by an Arabic number ranging from one to ten (S1, S2, S3...).

In order to categorize the level of evidence, the type of study was considered; the hierarchical classification was used in seven levels: Level I: Evidence of a systematic review or meta-analysis studies, the largest quantitative being identified in the Web of Science database $(n=87 ; 42.4 \%)$. Thorough and thorough reading allowed the selection of the final review sample, consisting of nine studies (100.0\%).

All the studies were published in international journals in the English language, highlighting 2015 as the year with the highest number of publications $(n=4 ; 44.4 \%)$. As regards origin, the United States stood out with three (33.3\%) published studies (S1, S6, S9) on the subject, followed by Israel, with two (22.2\%) studies (S7, S8). Cohort studies $(n=3 ; 33.3 \%)$ and case $(n=3 ; 33.3 \%)$, classified with evidence IV and VI, respectively, were predominant in relation to type and level of evidence (Chart 1).

Chart 1 - Characterization of the selected studies published from 2010 to 2015, Florianópolis, Santa Catarina state, Brazil

\begin{tabular}{|c|c|c|c|c|c|c|}
\hline Code & Title & $\begin{array}{c}\text { Year/ } \\
\text { Country }\end{array}$ & $\begin{array}{l}\text { Outlining/ } \\
\text { number of } \\
\text { patients }\end{array}$ & Objectives & Main results & NE \\
\hline S1 & $\begin{array}{l}\text { Face masks for } \\
\text { noninvasive } \\
\text { ventilation: } \\
\text { fit, excess skin } \\
\text { hydration, and } \\
\text { pressure ulcers }^{(11)}\end{array}$ & $\begin{array}{l}2015 \\
\text { United } \\
\text { States }\end{array}$ & $\begin{array}{l}\text { Prospective } \\
\text { cohort } \\
\mathrm{N}=50\end{array}$ & $\begin{array}{l}\text { To investigate the factors } \\
\text { that contribute to the } \\
\text { development of PI-related } \\
\text { mask of NIV. }\end{array}$ & $\begin{array}{l}\text { Of the participants, } 72 \% \text { presented PI related to the } \\
\text { NIV mask with } 61 \text { sites involved. Stage } 1 \text { injuries were } \\
\text { the most common. The risk of injury was higher for the } \\
\text { oronasal mask. The skin hydration differences were } \\
\text { correlated with the occurrence of injuries, and coverages } \\
\text { were indicated between the mask and the skin for MDRI } \\
\text { prevention. }\end{array}$ & IV \\
\hline $\mathrm{S} 2$ & $\begin{array}{l}\text { Unusual cause of a } \\
\text { facial pressure ulcer: } \\
\text { the helmet securing } \\
\text { the Sengstaken- } \\
\text { Blakemore tube }^{(12)}\end{array}$ & $\begin{array}{l}2015 \\
\text { Korea }\end{array}$ & $\begin{array}{l}\text { Case } \\
\mathrm{N}=1\end{array}$ & $\begin{array}{l}\text { Report a case of atypical } \\
\text { facial PI developed by a } \\
\text { helmet for SBT fixation. }\end{array}$ & $\begin{array}{l}\text { Woman, } 59 \text { years old with high digestive hemorrhage, } \\
\text { using SBT. Traction force was applied with } 1 \mathrm{~kg} \text { at the } \\
\text { proximal end of the SBT and a metal frame U-shaped } \\
\text { helmet around the face. After three days of use, there was } \\
\text { evidence of an injury in the frontal region of the skull with } \\
\text { cutaneous necrosis. There are general recommendations } \\
\text { for the prevention of MDRI such as: Evaluating the skin } \\
\text { daily and applying protective dressing. }\end{array}$ & VI \\
\hline
\end{tabular}




\begin{tabular}{|c|c|c|c|c|c|c|}
\hline S3 & $\begin{array}{l}\text { Facial skin breakdown } \\
\text { in patients with non- } \\
\text { invasive ventilation } \\
\text { devices: report of two } \\
\text { cases and indications } \\
\text { for treatment and } \\
\text { prevention }^{(13)}\end{array}$ & $\begin{array}{l}2015 \\
\text { Italy }\end{array}$ & $\begin{array}{l}\text { Case } \\
\mathrm{N}=2\end{array}$ & $\begin{array}{l}\text { To report two cases of PI } \\
\text { related to NIV. }\end{array}$ & $\begin{array}{l}\text { Case 1: Premature newborn ( } 28 \text { weeks), using nasal cannula } \\
\text { with continuous positive pressure. After } 4 \text { weeks he had an } \\
\text { injury in nasal columella. Case 2: Elderly ( } 71 \text { years) in NIV per } \\
\text { nasal oral mask. After } 11 \text { days he had injury with necrosis on } \\
\text { nasal, nasolabial and ment. Both were in critical condition, } \\
\text { with need for NIV } 24 \mathrm{~h} / \text { day. Treatment and prevention } \\
\text { measures such as disinfection, use of hyaluronic acid and } \\
\text { gauze protection of risk areas were reported. }\end{array}$ & $\mathrm{VI}$ \\
\hline S4 & $\begin{array}{l}\text { Saudi Arabian } \\
\text { adult intensive care } \\
\text { unit pressure ulcer } \\
\text { incidence and risk } \\
\text { factors: a prospective } \\
\text { cohort study }^{(14)}\end{array}$ & $\begin{array}{l}2015 \\
\text { Saudi } \\
\text { Arabia }\end{array}$ & $\begin{array}{l}\text { Prospective } \\
\text { cohort } \\
\mathrm{N}=84\end{array}$ & $\begin{array}{l}\text { To identify the incidence } \\
\text { and risk factors associated } \\
\text { with the development } \\
\text { of PI in adult patients at } \\
\text { two ICUs. }\end{array}$ & $\begin{array}{l}\text { The incidence of PI was } 39.3 \% \text {, being } 8.3 \% \text { MDRI. Among } \\
\text { the factors predictive of PI are: Age, length of stay in the } \\
\text { ICU, history of cardiovascular and renal diseases, time } \\
\text { of operation, emergency hospitalization, mechanical } \\
\text { ventilation and lower scores on the Braden Scale. No } \\
\text { preventive measures and treatment of MDRI were presented. }\end{array}$ & IV \\
\hline S5 & $\begin{array}{l}\text { Device-related } \\
\text { atypical pressure } \\
\text { ulcer after cardiac } \\
\text { surgery }^{(15)}\end{array}$ & $\begin{array}{l}2014 \\
\text { United } \\
\text { Kingdom }\end{array}$ & $\begin{array}{l}\text { Case } \\
\mathrm{N}=1\end{array}$ & $\begin{array}{l}\text { To report a case of } \\
\text { MDRl and to propose } \\
\text { an algorithm for the } \\
\text { prevention of these } \\
\text { injuries. }\end{array}$ & $\begin{array}{l}\text { Man, } 60 \text { years old, submitted to cardiac surgery. After } \\
\text { postoperative complications and prolonged hospitalization } \\
\text { in ICU, he developed stage IV MDRI in the posterior cervical } \\
\text { region attributed to fixation of the orotracheal tube. } \\
\text { Among the measures to prevent PI related to the use of } \\
\text { ventilation devices it is proposed to move the device. }\end{array}$ & $\mathrm{Vl}$ \\
\hline S6 & $\begin{array}{l}\text { A prospective } \\
\text { window into } \\
\text { medical device- } \\
\text { related pressure } \\
\text { ulcers in intensive }_{\text {care }^{(16)}}\end{array}$ & $\begin{array}{l}2014 \\
\text { Australia/ } \\
\text { United } \\
\text { States }\end{array}$ & $\begin{array}{l}\text { Multicentric } \\
\text { Cross- } \\
\text { sectional } \\
\mathrm{N}=483\end{array}$ & $\begin{array}{l}\text { To determine the } \\
\text { prevalence, severity, } \\
\text { location, etiology, } \\
\text { treatment and healing of } \\
\text { MDRI in ICU patients. }\end{array}$ & $\begin{array}{l}\text { The prevalence of MDRI was } 3.1 \% \text {. Nine of the } 15 \\
\text { patients were followed up, with an occurrence of } 11 \\
\text { injuries. There were two of stage 1, eight of stage } 2 \text { and } \\
\text { one of stage 3, most of them in the head and neck. } \\
\text { Endotracheal and nasogastric tubes caused most of } \\
\text { the injuries. For prevention and treatment indicated: } \\
\text { Repositioning and padding of the device, in addition to } \\
\text { skin cleansing and moisturizing. }\end{array}$ & $\mathrm{VI}$ \\
\hline S7 & $\begin{array}{l}\text { Cohort study } \\
\text { of atypical } \\
\text { pressure ulcers } \\
\text { development }^{(17)}\end{array}$ & $\begin{array}{l}2014 \\
\text { Israel }\end{array}$ & $\begin{array}{l}\text { Cohort } \\
\mathrm{N}=174\end{array}$ & $\begin{array}{l}\text { To analyze the occurrence } \\
\text { of atypical PIs and } \\
\text { the circumstances of } \\
\text { causality. }\end{array}$ & $\begin{array}{l}\text { The rate of occurrence of the injuries was } 21 \% \text {. The etiology } \\
\text { was determined, respectively, by severe spasticity, use } \\
\text { of medical devices and bone deformities. To prevent PI } \\
\text { related to TCT and IC, care is advised with the fixation of the } \\
\text { shoelace and the probe. }\end{array}$ & IV \\
\hline S8 & $\begin{array}{l}\text { A prospective pilot } \\
\text { study of atypical } \\
\text { pressure ulcer } \\
\text { presentation in } \\
\text { a skilled geriatric } \\
\text { nursing unit }{ }^{(18)}\end{array}$ & $\begin{array}{l}2011 \\
\text { Israel }\end{array}$ & $\begin{array}{l}\text { Descriptive } \\
\mathrm{N}=32\end{array}$ & $\begin{array}{l}\text { To describe the } \\
\text { occurrence, causes, } \\
\text { prevention, evaluation } \\
\text { and treatment of atypical } \\
\text { Pls. }\end{array}$ & $\begin{array}{l}\text { The occurrence rate of PIs was } 40 \% \text { ( } n=13) \text {. Of these, } \\
\text { six were associated with medical devices, four with } \\
\text { increased spasticity and three with bone deformity } \\
\text { - observed at the site of increased tone and muscle } \\
\text { pressure. It is indicated to replace the urethral catheter } \\
\text { with suprapublic to prevent MDRI. }\end{array}$ & $\mathrm{VI}$ \\
\hline S9 & $\begin{array}{l}\text { Medical } \\
\text { device related } \\
\text { pressure ulcers } \\
\text { in hospitalized } \\
\text { patients }^{(19)}\end{array}$ & $\begin{array}{l}2010 \\
\text { United } \\
\text { States }\end{array}$ & $\begin{array}{l}\text { Cross- } \\
\text { sectional } \\
\mathrm{N}=2079\end{array}$ & $\begin{array}{l}\text { To quantify and identify } \\
\text { risk factors for MDRI. }\end{array}$ & $\begin{array}{l}\text { The PI rate was 54\%. The proportion of patients with } \\
\text { MDRI was } 34.5 \% \text {. Patients in use of devices were } \\
\text { more likely to develop PI of any kind. The general } \\
\text { recommendations for the prevention of MDRI are } \\
\text { focused on skin evaluation, repositioning and fixation of } \\
\text { the device, work and multiprofessional education. }\end{array}$ & $\mathrm{VI}$ \\
\hline
\end{tabular}

Note - Code - Study code; LoE - Level of Evidence; PI - Pressure Injury; MDRI - Medical Device-Related Pressure Injury; NIV-Non-Invasive Ventilation; SBT - Sengstaken-Blakemore Tube; ICUs - Intensive Care Units; IC-Indwelling Catheter; TCT-Tracheostomy.

Chart 2 - Risk devices for Pressure Injuries and their frequency according to development sites and studies, Florianópolis, Santa Catarina state, Brazil, 2015.

\begin{tabular}{|c|c|c|c|}
\hline Risk device & Localization of MDRI & Occurrence (\%) & Study \\
\hline Non-Invasive Ventilation Mask & $\begin{array}{l}\text { Nose base } \\
\text { Face } \\
\text { Fontal region of the skull } \\
\text { Chin } \\
\text { Nasal columella } \\
\text { Nasolabial region }\end{array}$ & $\begin{array}{r}39.0 \\
30.0 \\
10.0 \\
3.0 \\
\text { UOS* } \\
\text { UOS* }\end{array}$ & $\begin{array}{l}\text { S1 } \\
\text { S1 } \\
\text { S1 } \\
\text { S1 } \\
\text { S3 } \\
\text { S3 }\end{array}$ \\
\hline Orotracheal tube & $\begin{array}{l}\text { Ear } \\
\text { Neck } \\
\text { Lip } \\
\text { Nose } \\
\text { Cervical posterior } \\
\text { Scalp }\end{array}$ & $\begin{array}{c}37.5 \\
25.0 \\
12.5 \\
12.5 \\
40.0 \\
\text { UOS* }\end{array}$ & $\begin{array}{l}\text { S4 } \\
\text { S4 } \\
\text { S4 } \\
\text { S4 } \\
\text { S7 } \\
\text { S5 }\end{array}$ \\
\hline Tracheostomy & $\begin{array}{l}\text { Cervical posterior } \\
\text { Neck } \\
\text { Stoma region }\end{array}$ & $\begin{array}{c}66.0 \\
10.0 \\
\text { UOS* }^{*}\end{array}$ & $\begin{array}{l}\text { S8 } \\
\text { S7 } \\
\text { S7 }\end{array}$ \\
\hline Nasogastric tube & Nose & 40.0 & S6 \\
\hline
\end{tabular}


Chart 2 (concluded)

\begin{tabular}{|c|c|c|c|}
\hline Risk device & Localization of MDRI & Occurrence (\%) & Study \\
\hline Gastrostomy tube & Region underlying the stoma & 10.0 & S7 \\
\hline Sengstaken-Blakemore tube helmet & Frontal region & UOS* & S2 \\
\hline Cervical collar & $\begin{array}{l}\text { Occipital region } \\
\text { Chin } \\
\text { Occipital region }\end{array}$ & $\begin{array}{l}10.0 \\
10.0 \\
\text { UOS* }\end{array}$ & $\begin{array}{l}\text { S7 } \\
\text { S7 } \\
\text { S9 }\end{array}$ \\
\hline Indwelling Catheter & $\begin{array}{l}\text { Urethra } \\
\text { Genital organ and urethral meatus }\end{array}$ & $\begin{array}{l}20.0 \\
17.0\end{array}$ & $\begin{array}{l}\text { S7 } \\
\text { S8 }\end{array}$ \\
\hline Radial Artery Catheter & Arm & UOS* $^{*}$ & S9 \\
\hline Immobilization splint & Hand & UOS* & S9 \\
\hline Anti-embolism socks & Heel & UOS* $^{*}$ & S9 \\
\hline
\end{tabular}

Note - MDRI - Medical Device-Related Pressure Injuries; UOS - Unethical Occurrence in the Study.

As for the areas of knowledge, five (55.6\%) studies (S4, S6, S7, S8 and S9) were developed by Nursing researchers and four (44.4\%) (S1, S2, S3 and S5) Medicine. Regarding the research method used in the studies, six (66.7\%) are of quantitative approach and three (33.3\%) are qualitative.

The analysis of the studies allowed to identify that the posterior cervical region and the nose obtained the highest frequencies of injuries produced by medical devices, respectively, $66.0 \%$ and $40.0 \%$. However, the frequency of injuries in nine sites (nasal columella, nasolabial region, scalp, tracheostomy stoma region, frontal, occipital, arm, hand and heel regions) was not recorded.
The devices that stood out due to $\mathrm{Pl}$ in six different places of the body were: The Non-Invasive Ventilation (NIV) mask and the orotracheal tube (Chart 2).

Regarding the prevention and treatment of MDRIs, studies (S1, S3, S5, S7 and S8) present specific recommendations according to the type of device (NIV mask, Tracheostomy and orotracheal tube, and Indwelling Catheter). General measures that can be applied to the patient using any device were also disclosed (S2, S5, S6, S9) (Chart 3).

No preventive or treatment recommendation for the lesions was pointed out by one of the studies (S4).

Chart 3 - Specific and general recommendations for the prevention and treatment of Medical Device-Related Pressure Injuries according to the studies, Florianópolis, Santa Catarina state, Brazil, 2015

\begin{tabular}{|c|c|}
\hline Specific recommendations & Study \\
\hline \multicolumn{2}{|l|}{ NIV mask } \\
\hline - Apply silicone or hydrogel foam cover between the mask and the skin. & S1 \\
\hline $\begin{array}{l}\text { - Protect the skin under the mask with padded bandage made with gauze, containing sodium chloride and hyaluronic acid. } \\
\text { Associated with the use of this protection, it is essential to systematically control the contact points between the skin and the } \\
\text { rigid parts of the mask, with rigorous follow-up (skin check every 3-4 hours), especially in premature and elderly, which represent } \\
\text { Patients at higher risk of developing PI. }\end{array}$ & S3 \\
\hline - Remove or move the mask from NIV 4/4h and evaluate the skin under the device. & S5 \\
\hline \multicolumn{2}{|l|}{ Tracheostomy tube } \\
\hline $\begin{array}{l}\text { - Use hydrocolloid plaque in the posterior cervical region for prevention and treatment of injuries caused by tracheostomy } \\
\text { shoelace. }\end{array}$ & S7 \\
\hline - Replace shoelace with a smooth, wider plastic frame. & S7 \\
\hline - Assess the need to decrease the diameter of the cannula. & S7 \\
\hline \multicolumn{2}{|l|}{ Orotracheal tube } \\
\hline - Move the device every 2 hours to evaluate the skin and labial mucosa. & S5 \\
\hline \multicolumn{2}{|l|}{ Indwelling Catheter } \\
\hline - Fix the probe to the side of the thigh, reducing the traction force of it. & S7 \\
\hline - Replace the urethral catheter with a suprapubbic. & S8 \\
\hline General recommendations & Study \\
\hline - Choose the size of the device according to the characteristics of the patient. & S2 \\
\hline - Question the need to maintain the use of the device or if it does not need to be replaced. & S5 \\
\hline $\begin{array}{l}\text { - Consider the application of protective dressing to reduce shear and friction (transparent films/hydrocolloid/silicone/foam), as } \\
\text { well as the use of dermal gel pads to reduce pressure and methods that decrease moisture (textile product with silver to remove } \\
\text { moisture in skin folds, especially in obese patients). }\end{array}$ & $\mathrm{S} 2, \mathrm{~S} 5, \mathrm{~S} 6$ \\
\hline
\end{tabular}




\begin{tabular}{|l|c|}
\hline General recommendations & Study \\
\hline - Remove or move the device daily to evaluate the skin, in addition to inspect it every 8 to $12 \mathrm{~h}$, and perform periodic repositioning & S2, S5, \\
of the device. & S6, S9 \\
- Avoid placing device on pressure sites with pre-existing Injury. & S2 \\
- Work in a multidisciplinary team and perform continuous education on the correct use of devices and measures to prevent skin \\
rupture.
\end{tabular}

Note - NIV - Non-Invasive Ventilation; PI - Pressure Injuries.

\section{DISCUSSION}

The analysis of the studies showed a predominance of publications in the year 2015, suggesting that the MDRI is a subject of contemporary notoriety. In addition, no article contemplated in the review was published in South America, which points, in this context, a gap in the production of knowledge on the subject, which deserves to be explored, including in Brazil, in order to reveal the convergences and divergences between the realities of the different countries.

Another aspect that drew attention to the studies is that the majority was developed by researchers in the area of Nursing, signaling that the professional category is concerned to study the problem of MDRI and to provide care to avoid this type of injury. Regarding the methodological approach of the researches, the quantitative one prevailed, a result that is in agreement with the research on patient safety in dissertations and theses of Nursing, in which there was a trend of studies related to the theme in the hospital setting and with emphasis on risk reduction of $\mathrm{PI}^{(20)}$. However, systematic reviews and Randomized Clinical Trials were not identified in the present study, which would configure better evidence to the findings.

Regarding the devices for the risk and development of MDRI, respiratory devices, such as NIV masks and orotracheal tube, have been shown to cause the most damage, a finding also found in a study carried out in the United States, in which these devices were responsible, respectively, for $30 \%$ to $70 \%$ of the MDRI in severe patients ${ }^{(21)}$. An explanation for this phenomenon is the priority placed on the airways, which often induces tight fixtures of the devices, causing injuries ${ }^{(22)}$.

In Turkey, research on the prevalence of MDRI and the risk factors for its development corroborated that the most frequent lesions were subsequently caused by the orotracheal tube, NIV masks, oximeters, $\mathrm{O} 2$ mask and nasal cannulae ${ }^{(23)}$.

The Pls located on the face are among the most frequent complications associated with the use of NIV masks, represented by the second highest percentage of injuries ${ }^{(11)}$ caused by the device. This finding resembles that of an investigation developed in Portugal, whose frequency of PI due to NIV was $26.7 \%$. The mean time of onset of the injuries was 3.3 days, with patients submitted to more hours of NIV per day, greater number of days in this type of ventilation and more days of hospitalization presented higher frequency of injuries ${ }^{(24)}$.
Immobilizing devices, such as cervical collar and splints, were also attributed to MDRI in the literature. In the Netherlands, the incidence of MDRI in patients with trauma with suspected spinal cord injury was $20.1 \%$. Immobilization devices were the ones that caused the most injury, and among others, the urinary and oxygen catheters, the orotracheal tube and the nasogastric tube ${ }^{(25)}$.

The results are corroborated by another study that related a number of devices considered potential to cause MDRI: Orotracheal tube; nasotracheal tube; Tracheostomy tube; $\mathrm{O} 2$ catheter; neck brace; Non-Invasive Ventilation mask; bladder catheter; and, fecal containment device. These devices may injure, respectively, lips and tongue, nose and nasal mucosa, furcula, cervical region, nose and ear, neck, clavicle, occipital region, chin, jaw, forehead, nose, cheeks, urethra, thighs, buttocks and perianal region ${ }^{(26)}$.

Regarding the prevention and treatment measures of MDRIs, analysis of the studies revealed general recommendations applied to any type of device, as well as specific ones, directed to the NIV mask, the Tracheostomy and orotracheal tube and the bladder catheter.

Overall measures to prevent and treat MDRIs included periodic skin assessment, repositioning of devices and use of dressings to reduce shear force. In this sense, a study carried out by US nurses summarizes three main measures to prevent these injuries: Consider the application of dressings that promote pressure redistribution and absorb body moisture in areas in contact with medical devices and fixers; apply dressings below medical devices, lift and/or move the device often to examine the skin below it and reposition for pressure relief. When repositioning does not relieve pressure, it is important not to create more pressure by placing tight bandages under and over the devices ${ }^{(26)}$.

This study evidenced that general measures aimed at healing are predominant in the treatment of MDRI, even in the case of injuries caused by specific medical devices. For the healing of the injuries, the preparation of the injured site is indicated, which implies in the control of the infection or inflammation and the exudate. In addition, stimulation of the epithelial borders is recommended through different intervention measures. In this sense, in addition to cleaning the injury and debridement, when necessary, dressings should be applied, whose choice must consider the professional's knowledge of the product, the available evidence and the characteristics of the patient. Other criteria to be evaluated in the dressing selection are: Its ability to maintain adequate moisture in the wound bed; need to address bacterial load; nature and volume 
of the exudate; pericutaneous skin condition; characteristics of the injury (stage, size, location, presence of tunnels and/or cavitations); and compatibility with clinical devices used ${ }^{(27)}$. It is also emphasized that the treatment modalities are influenced by clinical guidelines and local practice standards ${ }^{(28)}$.

Based on the recommendations presented in the present study, it is possible to plan quality and safe nursing care for patients using medical devices in any health care setting, especially in the hospital, where devices are often used in acute and chronic situations of health.

\section{Study limitations}

As limitations of the study it is pointed out the five-year time cut employed in the search strategy of publications, which may have excluded research on the subject published before or after this period. We did not identify systematic reviews and Randomized Clinical Trials in the search strategies, being, therefore, the categorization of the evidences based on studies considered of less methodological rigor.

\section{Contributions for the sectors of Nursing, Health or Public Policy}

The main contribution of this review is the identification of the risk devices for the $\mathrm{PI}$ and their location, as well as the practices of prevention and treatment of the injuries. It is hoped that the findings can be applied to patient care by subsidizing nurses in the implementation of preventive and treatment measures to reduce the occurrence of MDRIs.

\section{CONCLUSION}

MDRIs are frequent problems in health institutions, with the posterior cervical region and the nose being the most frequently affected sites. Eleven devices of risk for the development of the injuries were identified: Non-Invasive Ventilation masks; orotracheal tube; Tracheostomy; nasogastric tube; gastrostomy tube; Sengstaken-Blakemore Tube; neck brace; Indwelling Catheter; radial artery catheter; immobilizing splint and; stockings. Of these, the Non-Invasive Ventilation masks and the orotracheal tube were highlighted, as they caused injury in six different body locations.

Regarding the prevention and treatment of the injuries, there are general and specific to the type of device used, most of them being simple and mainly based on the periodic evaluation of the skin under the devices. It is also recommended that healthcare professionals always ask themselves if maintenance of the device is fundamental for the patient, since the best prevention is still the removal of the device when there is no longer any indication of use.

Although it is possible to identify that, in general, knowledge production on the subject is growing, new studies are suggested in the different care settings, in South America and especially in Brazil, due to the different realities of care that present themselves.

\section{REFERENCES}

1. World Health Organization-WHO. World alliance for patient safety: forward programme[Internet]. Geneva: World Health Organization; 2004 [cited 2018 Jul 12]. Available from: http://www.who.int/patientsafety/en/brochure_final.pdf

2. Ministério da Saúde (BR). Portaria n. 529, de 1º. de abril de 2013. Institui o Programa Nacional de Segurança do Paciente (PNSP) [Internet]. Brasília; 2013 [cited 2018 May 22]. Available from: http://bvsms.saude.gov.br/bvs/saudelegis/gm/2013/prt0529_01_04_2013.html.

3. National Pressure Ulcer Advisory Panel. Staging Consensus Conference that was held. [Internet]. 2016 [cited 2018 May 22]. Available from: http://www.npuap.org/resources/educational-and-clinical-resources/npuap-pressure-injury-stages/

4. Coleman S, Gorecki C, Nelson EA, Closs SJ, Defloor T, Halfens R, et al. Patient risk factors for pressure ulcer development: systematic review. Int J Nurs Stud [Internet]. 2013 [cited 2017 Mai 02]; 50(7):974-1003. Available from: https://www.sciencedirect.com/science/article/pii/ S002074891200421X?via\%3Dihub

5. Fletcher J. Device related pressure ulcers made easy. Wounds [Internet]. 2012 [cited 2018 Feb 05];8(2):1-4. Available from: https://www. smith-nephew.com/global/assets/pdf/products/wound/v1-aderma_link.pdf

6. Murray JS, Noonan C, Quigley S, Curley MA. Medical device-related hospital-acquired pressure ulcers in children: an integrative review. J Pediatr Nurs [Internet]. 2013[cited 2018 Feb 05];28(6):585-95. Available from: https://www.sciencedirect.com/science/article/pii/ S0882596313001930?via\%3Dihub

7. Soares CB, Hoga LAK, Peduzzi M, Sangaleti C, Yonekura T, Silva DRAD. Integrative review: concepts and methods used in nursing. Rev Esc Enferm USP [Internet]. 2014 [cited 2018 Feb 05];48(2):335-45. Available from: http://www.scielo.br/pdf/reeusp/v48n2/0080-6234reeusp-48-02-335.pdf

8. Ganong LH. Integrative reviews of nursing research. Res Nurs Health [Internet]. 1987[cited 2018 Feb 05];10(1):1-11. Available from: https:// www.ncbi.nlm.nih.gov/pubmed/3644366

9. Galvão TF, Pansani, TSA, Harrad D. Principais itens para relatar revisões sistemáticas e meta-análises: a recomendação PRISMA. Epidemiol Serv Saude [Internet]. 2015 [cited 2018 Mai 22]; 24(2):335-42. Available from: http://www.scielo.br/pdf/ress/v24n2/2237-9622ress-24-02-00335.pdf

10. Melnyk BM, Gallagher-Ford L, Fineout-Overrholt E. Implementing the evidence-based practice (EBP) competencies in healthcare: a practical guide to improving quality, safety, and outcomes. In: Sigma Theta Tau International. Indianapolis: 2016. p.78-9

11. Visscher MO, White CC, Jones JM, Cahill T, Jones DC, Pan BS. Face masks for noninvasive ventilation: fit, excess skin hydration, and pressure 
ulcers. Respir Care [Internet]. 2015 [cited 2018 Feb 07];60(11):1536-47. Available from: http://rc.rcjournal.com/content/60/11/1536

12. Kim SM, Ju RK, Lee JH, Jun YJ, Kim Yj. Unusual cause of a facial pressure ulcer: the helmet securing the Sengstaken-Blakemore tube. J Wound Care [Internet]. 2015 [cited 2018 Feb 07];24(Suppl-6). Available from: https://www.magonlinelibrary.com/doi/10.12968/jowc.2015.24.Sup6.S14

13. Maruccia M, Ruggieri M, Onesti MG. Facial skin breakdown in patients with non-invasive ventilation devices: report of two cases and indications for treatment and prevention. Int Wound J [Internet]. 2015 [cited 2018 Feb 07];12(4):451-5. Available from: https://www.ncbi. nlm.nih.gov/pubmed/23870043

14. Tayyib N, Coyer F, Lewis P. Saudi Arabian adult intensive care unit pressure ulcer incidence and risk factors: a prospective cohort study. Int Wound J [Internet]. 2015 [cited 2018 Feb 07]; 3(5):912-9. Available from: https://www.ncbi.nlm.nih.gov/pubmed/25662591

15. Glasgow D, Millen IS, Nzewi OC, Varadaraiaran B. Device-related atypical pressure ulcer after cardiac surgery. J Wound Care [Internet]. 2014 [cited 2018 Feb 07];23(8):383-7. Available from: https://www.ncbi.nlm.nih.gov/pubmed/25139595

16. Coyer FM, Stotts NA, Blackman. A prospective window into medical device-related pressure ulcers in intensive care. Int Wound J [Internet]. 2014 [cited 2018 Feb 07];11(6):656-64. Available from: https://www.ncbi.nlm.nih.gov/pubmed/23374630

17. Jaul E. Cohort study of atypical pressure ulcers development. Int Wound J [Internet]. 2014 [cited 2018 Feb 07];11(6):696-700. Available from: https://www.ncbi.nlm.nih.gov/pubmed/23374746

18. Jaul E. A prospective pilot study of atypical pressure ulcer presentation in a skilled geriatric nursing unit. Ostomy Wound Manage [Internet]. 2011 [cited 2018 Feb 07];57(2):49-54. Available from: https://www.ncbi.nlm.nih.gov/pubmed/21350272

19. Black JM, Cuddigan JE, Walko MA, Didier LA, Lander MJ, Kelpe MR. Medical device related pressure ulcers in hospitalized patients. Int Wound J [Internet]. 2010 [cited 2018 Feb 07];7(5):358-65. Available from: https://www.ncbi.nlm.nih.gov/pubmed/20561094

20. Gomes ATL, Salvador PTCO, Rodrigues CCFM, Silva MF, Ferreira LL, Santos VEP. Patient safety in nursing paths in Brazil. Rev Bras Enferm [Internet]. 2017 [cited 2018 Fev 05];70(1):146-54. Available from: http://www.scielo.br/pdf/reben/v70n1/en_0034-7167-reben-70-01-0146.pdf

21. Padula CA, Paradis H, Goodwin R, Lynch J, Hegerich-Bartula D. Prevention of medical device related pressure injuries associated with respiratory equipment use in a critical care unit: a quality improvement project. J Wound Ostomy Continence Nurs [Internet]. 2017 [cited 2018 Fev 05];44(2):138-41. Available from: https://www.ncbi.nlm.nih.gov/pubmed/28267119

22. Black JM, Kalowes P. Medical device-related pressure ulcers. Chronic Wound Care Manag and Res[Internet]. 2016[cited 2018 Feb 06];(3):91-9. Available from: https://www.dovepress.com/medical-device-related-pressure-ulcers-peer-reviewed-article-CWCMR

23. Hanonu S, Karadg AA. Prospective, descriptive study to determine the rate and characteristics of and risk factors for the development of medical device-related pressure ulcers in intensive care units. Ostomy Wound Manag[Internet]. 2016 [cited 2018 Feb 07];62(2):12-22. Available from: https://www.ncbi.nlm.nih.gov/pubmed/26901386

24. Martins MDS, Ribas PSC, Sousa JRA, Silva NAP, Preto LSR, Correia TIG. Facial pressure ulcers in inpatients undergoing non-invasive ventilation in intermediate care units. Rev Enferm Ref[Internet]. 2016 [cited 2018 Feb 07];4(10):103-11. Available from: http://www.scielo.mec.pt/pdf/ ref/vserIVn10/serIVn10a12.pdf

25. Ham WH, Schoonhoven L, Schuurmans MJ, Leenen LP. Pressure ulcers in trauma patients with suspected spine injury: a prospective cohort study with emphasis on device-related pressure ulcers. Int Wound J [Internet]. 2017 [cited 2018 Feb 05];14(1):104-11. Available from: https:// www.ncbi.nlm.nih.gov/pubmed/26767917

26. Black JM, Alves P, Brindle CT, Dealey C, Santamaria N, Call E, et al. Use of wound dressings to enhance prevention of pressure ulcers caused by medical devices. Int Wound J [Internet]. 2015 [cited 2018 Feb 05];12(3):322-7. Available from: https://www.ncbi.nlm.nih.gov/ pubmed/23809279

27. Raurell-Torredà M, Romero-Collado A, Rodríguez-Palma M, Farrés-Tarafa M, Martí JD, Hurtado-Pardos B, et al. Prevention and treatment of skin lesions associated with non-invasive mechanical ventilation: recommendations of experts. Enferm Intens [Internet]. 2017 [cited $2018 \mathrm{Jul}$ 12];28(1):31-41. Available from: http://www.elsevier.es/en-revista-enfermeria-intensiva-english-edition--430-pdf-S2529984017300083-S300

28. Saha S, Smith MEB, Totten A, Fu R, Wasson N, Rahman B, et al. Pressure ulcer treatment strategies: comparative effectiveness[Internet]. Rockville, MD: Agency for Healthcare Research and Quality; 2013 [cited 2018 Jul 12]. Available from: https://www.ncbi.nlm.nih.gov/books/ NBK143657/pdf/Bookshelf_NBK143657.pdf 